九州大学学術情報リポジトリ

Kyushu University Institutional Repository

\title{
A Simple Population Model for Phage Reproduction
}

Gani, Joseph Mark

Australian National University

https://doi.org/10.5109/13002

出版情報: 統計数理研究. 10 (3/4), pp. 1-3, 1962-10. Research Association of Statistical Sciences バージョン :

権利関係 : 


\title{
A SIMPLE POPULATION MODEL FOR PHAGE REPRODUCTION
}

\author{
By
}

\author{
J. GANI
}

(Received June 5th, 1961)

In a recent paper on phage crosses, Hershey (1958) has raised a number of interesting problems in population and genetic processes. A very simplified model of phage reproduction may be imagined as follows: at time $\boldsymbol{t}=0$ let $\boldsymbol{n}$ phage particles be released in a medium containing $N>n$ bacteria, and penetrate (infect) some bacteria, each with a probability $0<p<1$ of success. Only the bacteria free of phages reproduce in an ordinary birthdeath process with constant parameters $\lambda>\mu>0$; meanwhile in any infected bacterium, the number of phages may be considered to grow in a birth process with parameter $\alpha$. When exactly $r$ phages are produced, the bacterium dies, and releases these particles; they immediately infect more bacteria, and the process continues until all bacteria are killed. We are interested in the time of extinction $T$ of the bacteria.

We adopt as our basic time unit $\tau$ the mean time taken by an infected bacterium to break open. In the phage birth process, the probability that an $r$-th phage is produced in the interval $t, t+\delta t$ is

$$
P_{r-1}(t)(r-1) \alpha \delta t,
$$

where $\quad P_{r-1}(t)=e^{-x t}\left(1-e^{-\alpha t}\right)^{r-2}$ is the probability that there are $r-1$ phages at time $t$. Thus the mean time $\tau$ for a bacterium to break open is

$$
\tau=\int_{0}^{\infty} t e^{-\alpha t}\left(1-e^{-\alpha t}\right)^{r-2}(r-1) \alpha d t=\alpha^{-1} \Sigma_{j=1}^{r-1}(-1)^{j+1}\left(\begin{array}{c}
r-1 \\
j
\end{array}\right) j^{-1} \text {. }
$$

Starting with $i$ phage-free bacteria, then after an interval of time $\tau$, the average number of bacteria will be $i e^{\beta \tau}$ where $\beta=\lambda-\mu>0$. Clearly the average numbers of infected and phage-free bacteria just after times $0, \tau$, $2 \tau, \cdots$ will be :

\begin{tabular}{l|c|c}
\hline Times & Infected bacteria & \multicolumn{1}{|c}{ Phage-free bacteria } \\
\hline$O_{+}$ & $n p$ & $N-n p$ \\
$\tau_{+}$ & $n p^{2} r$ & $(N-n p) e^{\beta \tau}-n p^{2} r$ \\
$2 \tau_{+}$ & $n p^{3} r^{2}$ & $(N-n p) e^{2 \beta \tau}-n p^{2} r e^{\beta \tau}-n p^{3} r^{2}$ \\
$3 \tau_{+}$ & $n p^{4} r^{3}$ & $(N-n p) e^{3 \beta \tau}-n p^{2} r e^{2 \beta \tau}-n p^{3} r^{2} e^{\beta \tau}-n p^{4} r^{3}$ \\
$\cdots$ & $\cdots$ & $\cdots$ \\
\hline
\end{tabular}


In general, just after time $j \tau$, there will be $n p^{i+1} \boldsymbol{r}^{j}$ infected bacteria, and

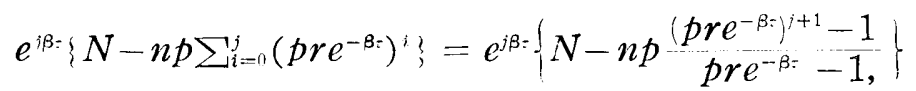

phage free bacteria.

For all the bacteria to die by time $T=(j+1) \tau_{+},(j \geq 0)$, we require that

$$
e^{\beta=}\left\{N-n p \frac{\left(p r e^{-\beta \tau}\right)^{j+1}-1}{p r e^{-\beta=}-1}\right\}>0 \geq e^{(j+1) \beta=}\left\{N-n p \frac{\left(p r e^{-9 s}\right)^{j+2}-1}{p r e^{-\beta=}-1}\right\}
$$

or, after taking logarithms and simplifying (if $p r e^{-\beta=}>1$ ), we find that

$$
\frac{\log \left\{1+\frac{N}{n p}\left(p r e^{-\beta \tau}-1\right)\right\}}{\log p r e^{-\beta=}}-2 \leq j<\frac{\log \left\{1+\frac{N}{n p}\left(p r e^{-\beta=}-1\right)\right\}}{\log p r e^{-\beta=}}-1 .
$$

To gain some idea of the speed of the process, let us take $N=10^{6}$, $\tau=30$ (minutes), $\beta=.1, r=200, p=.7$; the following table gives values for $T$ for different values of $n$.

\begin{tabular}{l|c|c}
\hline \multicolumn{1}{c|}{$n$} & $h=j+1$ & $T=h \tau$ \\
\hline $10^{3}$ & 4 & $T=120$ \\
$10^{4}$ & 3 & $T=90$ \\
$10^{5}$ & 2 & $T=60$ \\
$10^{6}$ & 1 & $T=30$ \\
$10^{k}(k \geq 7)$ & 0 & $T=0$ \\
\hline
\end{tabular}

A far more interesting and complicated problem is the stochastic treatment of the present model. A second realistic problem arises if phage reproduction in an infected bacterium is treated as a birth-death process in which dead phages are in fact " mature", and can no longer reproduce; when the bacterium breaks open after the mature phages reach the number $\boldsymbol{r}$, it is these only which are infective. Such a stochastic model would require the knowledge of the probabilities that $r$ deaths have occurred in a birth-death process: this problem has not been fully solved. However, if the birth and death (maturation) parameters are $\eta$ and $r$ respectively $(\eta>$ $r>0$ ), the deterministic approximation will give for the number $N(t)$ of survivors at time $t$

$$
N(t)=e^{(\eta-r) t},
$$

and the time $\tau$ for $r$ phages to have matured would then be given by

$$
r=\int_{0}^{\tau} \gamma e^{(\eta-\gamma) t} d t
$$

whence

$$
\tau=(\eta-\gamma)^{-1} \log \left\{1+(\eta-\gamma) \boldsymbol{r} \gamma^{-1}\right\} .
$$


With this value for $\tau$, instead of the previous value (1), the remaining treatment remains unchanged for a deterministic model.

\section{References}

Hershey, A. D. The production of recombinants in phage crosses. Cold Spring Harbor Symposia on Quantitative Biology, 23 (1958), 19-46.

Australian National University 